LASCELles, J. (1956). J. gen. Microbiol. 15, 404-416

\title{
An Assay of Iron Protoporphyrin based on the Reduction of Nitrate by a variant Strain of Staphylococcus aureus; Synthesis of Iron Protoporphyrin by Suspensions of Rhodopseudomonas spheroides
}

\author{
By JUNE LASCELLES* \\ Microbiology Unit, Department of Biochemistry, University of Oxford
}

SUMMARY : A growth requirement for haematin by a streptomycin-resistant strain of Staphylococcus aureus was abolished by adding pyruvate or acetate. Growth in the absence of haematin was improved by addition of purines and uracil. Under anaerobic conditions growth oecurred in the presence of nitrate when haematin was added. Suspensions of organisms grown in the absence of haematin reduced nitrate to nitrite when incubated in buffered glucose with haematin, and the amount of nitrite formed was proportional to the concentration of haematin over a range from 0.03 to $0.25 \mu \mathrm{m}$-mole/ml. This method was used to assay iron protoporphyrin formed by suspensions of Rhodopseudomonas spheroides. This organism synthesizes iron protoporphyrin as well as free porphyrins when incubated anaerobically in the light with $\delta$-aminolaevulic acid, iron salts and an oxidizable substrate; cobalt ions inhibit the formation of iron protoporphyrin.

Few bacteria have been found to require haematin for growth though it is a nutrient essential for many protozoa (Lwoff, 1951). The best known example of a requirement for haematin in bacteria is that of Haemophilus influenzae; growth is also promoted by the corresponding free porphyrin, protoporphyrin (Granick \& Gilder, 1946; Gilder \& Granick, 1947). Jensen \& Thofern (1953a) isolated a streptomycin-resistant strain of Staphylococcus aureus which required added haematin for growth under certain conditions. This organism differs from Haemophilus influenzae in that haematin is not replaced by other iron porphyrins or by protoporphyrin. This staphylococcus variant when grown with haematin contains a cytochrome system similar to that of the parent strain grown in the absence of haematin (Jensen \& Thofern, 1953a, 1954). The variant organism grows in the absence of haematin in a liquid medium containing tryptic digest of casein and glucose, and under these conditions the cells contain no detectable cytochrome. Also, they neither consume oxygen with glucose as substrate nor possess catalase activity (Jensen \& Thofern, 1953 $a$ ). Addition of haematin to suspensions of the exacting variant restores both respiratory and catalase activity (Jensen \& Thofern, 1953b).

In the present work the variant strain of Jensen \& Thofern was first examined with a view to obtaining a method for the microbiological assay of haematin or other forms of iron protoporphyrin. Since the conditions under which it needs this substance for growth are limited, an assay method which used growth response as criterion was not practicable. However, the ability of

* External Scientific Staff, Medical Research Council. 
suspensions of the variant staphylococcus to reduce nitrate to nitrite was found to depend on the concentration of haematin added. This assay method has been used to study synthesis of iron protoporphyrin by suspensions of Rhodopseudomonas spheroides, a member of the Athiorhodaceae (van Niel, 1944). The haematin-like material formed by Rhodopseudomonas spheroides is hereafter referred to as iron protoporphyrin since it is not known whether the iron is in the ferric or ferrous state.

The photosynthetic bacteria are rich in haematin compounds as well as bacteriochlorophyll (Elsden, 1954; Vernon \& Kamen, 1954; Kamen, 1955). Some of them also form considerable amounts of free porphyrin under conditions where synthesis of bacteriochlorophyll is limited by iron deficiency (Lascelles, 1955). The concurrent formation of free iron protoporphyrin and porphyrins from $\delta$-aminolaevulic acid has been studied in the present work.

\section{METHODS}

Organisms. Staphylococcus aureus, the streptomycin-resistant variant requiring haematin for growth (Strain SG 511 Var) was obtained from Dr J. Jensen. Some of its properties have been described by Jensen \& Thofern $(1953 a-c, 1954)$. It was maintained by monthly subculture on chocolate agar slopes which were incubated $18 \mathrm{hr}$. at $37^{\circ}$ and then stored at $4^{\circ}$. Details about Rhodopseudomonas spheroides have been given previously (Lascelles, 1956).

Media. The medium (medium A) used for the preparation of suspensions of the staphylococci contained ( $\%, w / v)$ : peptone (Evans Medical Supplies Ltd., Liverpool, England), 1.4; Marmite (a commercial autolysate of yeast), $0 \cdot 4$; glucose, $1 ; \mathrm{K}_{2} \mathrm{HPO}_{4}, 0 \cdot 8$; sodium acetate (trihydrate), $0 \cdot 16$; the $\mathrm{pH}$ value was 7·4. It was essential to prepare this medium immediately before use to obtain organisms with maximum activity. The basal medium (medium B) for growth tests was based on acid hydrolysed casein (vitamin-free) and was similar to medium B of Lascelles \& Woods (1952) except that the glucose concentration was increased to $0.05 \mathrm{M}$; the glucose was added after the medium had been autoclaved.

Rhodopseudomonas spheroides was grown on the chemically defined medium $\mathrm{S}$ described previously (Lascelles, 1956).

Growth experiments with the staphylococcus. Growth tests were carried out in $150 \times 18 \mathrm{~mm}$. tubes containing $2 \mathrm{ml}$. (final volume) of medium $\mathrm{B}$, which was autoclaved at $10 \mathrm{lb}$./sq.in. for $7 \mathrm{~min}$.; glucose, haematin and protoporphyrin were added after autoclaving. The inoculum was an aqueous suspension of organisms from an $18 \mathrm{hr}$. culture on a chocolate agar slope; each tube was sown with about $4 \times 10^{5}$ organisms $\left(0 \cdot 12 \mu \mathrm{g}\right.$. dry wt.) and incubated at $37^{\circ}$ in a sloped position in air or in an atmosphere of $5 \%(v / v) \mathrm{CO}_{2}$ in $\mathrm{H}_{2}$ in a McIntosh and Fildes jar.

Growth was measured on an EEL photoelectric colorimeter (Evans Electroselenium Co. Ltd., Harlow, Essex, England) using $6 \mathrm{~mm}$. tubes and a neutral density filter; the instrument was adjusted to give a reading of zero with uninoculated medium. A culture containing $0 \cdot 14 \mathrm{mg}$. dry wt. organisms $/ \mathrm{ml}$. 
gave a reading of 10 ; there was a linear relationship between instrument reading and dry weight of organisms up to a scale reading of 40.

Experiments with suspensions of the variant staphylococcus. Erlenmeyer flasks $(250 \mathrm{ml}$.) containing $125 \mathrm{ml}$. medium A were sown with $0.25 \mathrm{ml}$. of an aqueous suspension containing about $4 \times 10^{8}$ organisms $/ \mathrm{ml}$. derived from an $18 \mathrm{hr}$. chocolate agar slope; they were incubated for $18 \mathrm{hr}$. at $37^{\circ}$. The organisms were harvested by centrifuging, washed in $100 \mathrm{ml} .0 \cdot 85 \%(\mathrm{w} / \mathrm{v}) \mathrm{NaCl}$ and suspended in water to give a concentration of 7-9 mg. dry wt. organisms/ml. The reaction mixture used for the assay of iron protoporphyrin was as follows: organisms, 2-3 mg. dry wt.; phosphate buffer $\mathrm{pH} \mathrm{6.9,} \mathrm{0.1} \mathrm{m} ; \mathrm{NaNO}_{3}, 0.008 \mathrm{M}$; glucose, $0.02 \mathrm{M}$; after addition of haematin or the samples under assay the final volume was $2.5 \mathrm{ml}$. Incubation was in $120 \times 15 \mathrm{~mm}$. tubes for $3-5 \mathrm{hr}$. at $37^{\circ}$.

Experiments with Rhodopseudomonas spheroides. Organisms were grown anaerobically in the light and harvested by the methods described previously (Lascelles, 1956). Synthesis of porphyrins and iron protoporphyrin was followed in mixtures containing: washed organisms, 2.5-4 mg. dry wt.; phosphate buffer $\mathrm{pH} 6.9,0.08 \mathrm{M} ; \mathrm{MgSO}_{4}, 8 \times 10^{-4} \mathrm{M}$; sodium fumarate, $0.004 \mathrm{M}$; $\delta$-aminolaevulic acid hydrochloride, $0.002 \mathrm{M}$; iron citrate, various concentrations (see below); the final volume was $2.5 \mathrm{ml}$. Incubation was at $34^{\circ}$ in Thunberg tubes filled with $\mathrm{H}_{2}$; the tubes were stood in front of banks of tungsten lamps (40-60 W.) and the intensity of light falling on them was about $250 \mathrm{ft}$.c.

Estimation of nitrite. The concentration of nitrite formed by suspensions of the staphylococcus was estimated in the supernatant fluid after removal of the organisms by centrifuging. It was estimated colorimetrically by a method based on the Griess-Ilosvay reaction, similar to that described by Rider \& Mellon (1946). The reagents were: $(a)$ sulphanilic acid, $0 \cdot 3 \%(\mathrm{w} / \mathrm{v})$ dissolved in a mixture of $\mathrm{N}-\mathrm{HCl}$ and $8.5 \mathrm{~N}$-acetic acid; $(b) \alpha$-naphthylamine, $0.6 \%(\mathrm{w} / \mathrm{v})$ in $0.2 \mathrm{~N}-\mathrm{HCl}$. The sample $(0.1-1 \mathrm{ml}$.) was mixed with $0.5 \mathrm{ml}$. sulphanilic acid reagent; after standing for $3 \mathrm{~min}$., $0.25 \mathrm{ml}$. $\alpha$-naphthylamine and $0.5 \mathrm{ml}$. $2 \mathrm{M}$-sodium acetate were added and the final volume brought to $5 \mathrm{ml}$. with water. The colour developed after 20-30 min. was read on the EEL photoelectric colorimeter (Evans Electroselenium Co. Ltd.,) using $11 \mathrm{~mm}$. tubes and EEL filter no. 623 (transmission peak at $520 \mathrm{~m} \mu$.). Sodium nitrite was used as standard; stock solutions $(0 \cdot 1 \mathrm{M})$ were stored in the dark at $0^{\circ}$ and were diluted immediately before use. The standard series, included in each assay, ranged from $0 \cdot 2$ to $2 \mu \mathrm{m}$-moles $\mathrm{NaNO}_{2} / \mathrm{ml}$; t the relation between EEL reading and concentration of nitrite was linear between these limits.

Chemical estimation of haematin. This was estimated after conversion to the pyridine haemochromogen derivative. Samples containing 5-50 $\mu \mathrm{m}$.-moles haematin in $0.01 \mathrm{~N}-\mathrm{NaOH}$ were mixed with pyridine $(50 \%, \mathrm{v} / \mathrm{v})$ and reduced with about $5 \mathrm{mg}$. sodium dithionite. The optical density at $558 \mathrm{~m} \mu$. was measured on a spectrophotometer (Model SP-600, Unicam Instruments Ltd., Cambridge, England) and the concentration of haematin calculated from the extinction coefficient for the pyridine haemochromogen derivative of protohaem determined by Drabkin (1942). 
Estimation of porphyrins. The methods described by Lascelles (1956) for the determination of total porphyrin and the estimation of the relative proportion of copro- and protoporphyrin were used.

Special chemicals. Solutions of haematin were prepared by dissolving 2-3 mg. haemin (ferric protoporphyrin chloride obtained from British Drug Houses Ltd., Dorset, England) in $5 \mathrm{ml} .0 \cdot 01 \mathrm{~N}-\mathrm{NaOH}$, thereby converting it to haematin (Lemberg \& Legge, 1949); dilutions were made in water. The concentration of haematin in each stock solution was determined spectrophotometrically. Fresh solutions were used since their biological activity decreased rapidly even on storage in the dark at $0^{\circ}$.

Protoporphyrin was obtained from Light and Co. Ltd. (Colnbrook, Bucks, England). Stock solutions (in $0.01 \mathrm{~N}-\mathrm{NaOH}$ ) contained about $500 \mu \mathrm{g}$. protoporphyrin/ml.; the concentration was determined spectrophotometrically (Grinstein \& Wintrobe, 1948).

Stock solutions of iron citrate $\left(4 \times 10^{-3} \mathrm{M}\right.$ with respect to iron) were made by dissolving $157 \mathrm{mg}$. ferrous ammonium sulphate (hexahydrate) and $236 \mathrm{mg}$. sodium citrate (dihydrate) in $100 \mathrm{ml}$. water.

\section{RESULTS}

\section{Requirement of growing cultures of the variant staphylococcus for haematin}

Aerobic growth. Haematin was required for growth on medium B when incubation was in air; maximum growth was attained with $3 \times 10^{-8} \mathrm{M}$ haematin (Fig. 1). Protoporphyrin (up to $10^{-5} \mathrm{M}$ ) was inactive even when the medium was supplemented with iron $\left(2 \times 10^{-5} \mathrm{M}\right)$. These observations are in accord with those of Jensen \& Thoferi: (1953a).

Replacement of haematin. Growth of the staphylococci occurred in the absence of added haematin when medium $B$ was supplemented with sodium acetate or pyruvate. Under these conditions the further addition of a mixture containing adenine, xanthine and uracil brought the amount of growth up to that attained by adding haematin alone (Table 1 ). The nucleic acid derivatives were ineffective in the absence of acetate or pyruvate.

The concentration at which pyruvate and acetate were active was relatively low, suggesting that they were not acting merely as sources of energy (Table 2). Moreover, glucose was required for growth with acetate, while in the presence of pyruvate only slight growth occurred when glucose was omitted (Table 2). Glucose apparently provided the major source of energy for growth while pyruvate and acetate behaved as essential metabolites possibly needed for biosynthetic processes. They were not acting as precursors of haematin for the staphylococcus since organisms grown in their presence contained no detectable cytochrome nor did they show oxygen uptake when incubated with glucose. On the other hand, organisms grown with haematin contained cytochrome pigments and showed vigorous oxygen uptake with glucose as substrate.

Anaerobic growth in the presence of nitrate. The variant staphylococcus did not grow on medium $\mathbf{B}$ under anaerobic conditions either in the presence or absence of haematin. When nitrate was added to the medium growth occurred, 
Table 1. Growth response of the staphylococcus variant to haematin, acetate, pyruvate or nucleic acid derivatives

Medium B was supplemented as shown. The mixture of nucleic acid derivatives (PU mixture) contained adenine, xanthine and uracil (each $10^{-4} \mathrm{M}$ final conen.). Incubation was for $24 \mathrm{hr}$. in air.

\begin{tabular}{|c|c|c|c|c|}
\hline \multicolumn{4}{|c|}{ Additions } & \multirow{2}{*}{$\begin{array}{c}\text { Relative degree } \\
\text { of growth } \\
\text { (EEL reading) }\end{array}$} \\
\hline $\begin{array}{c}\text { Haematin } \\
\left(10^{-6} \mathrm{M}\right)\end{array}$ & $\begin{array}{c}\text { PU } \\
\text { mixture }\end{array}$ & $\begin{array}{c}\text { Na-acetate } \\
\left(10^{-2} \mathrm{M}\right)\end{array}$ & $\begin{array}{l}\text { Na-pyruvate } \\
\left(10^{-2} M\right)\end{array}$ & \\
\hline- & - & - & - & 0 \\
\hline+ & - & - & - & 33 \\
\hline- & + & - & - & 0 \\
\hline- & - & + & - & 16 \\
\hline- & + & + & - & 27 \\
\hline- & - & - & + & 29 \\
\hline- & + & - & + & 35 \\
\hline+ & + & - & - & 33 \\
\hline+ & + & + & - & 34 \\
\hline+ & + & - & + & 35 \\
\hline
\end{tabular}

Table 2. Growth response of the haematin-requiring staphylococcus variant to pyruvate, acetate and glucose

Medium $B$ without glucose was supplemented with adenine, xanthine and uracil (each $10^{-4} \mathrm{M}$ ) with further additions as shown. Incubation was for $24 \mathrm{hr}$. in air.

Additions

$\begin{array}{ccc}\text { Na-acetate } & \text { Na-pyruvate } & \text { Glucose } \\ (\mathrm{M}) & (\mathrm{M}) & (\mathbf{0 . 0 5} \mathbf{M}) \\ - & - & + \\ 3 \times 10^{-4} & - & + \\ 1 \times 10^{-3} & - & + \\ 3 \times 10^{-3} & - & + \\ 1 \times 10^{-2} & - & + \\ 1 \times 10^{-2} & \mathbf{3} & - \\ - & 1 \times 10^{-4} & + \\ - & 3 \times 10^{-3} & + \\ - & 1 \times 10^{-2} & + \\ - & 1 \times 10^{-2} & + \\ - & & -\end{array}$

Relative degree of growth

(EEL reading)

but only in the presence of haematin; nitrite was found in such cultures. The concentration of haematin required for maximum growth on nitrate was similar to that needed for aerobic growth in the absence of nitrate; maximum growth under both conditions was also similar (Fig. 1). This suggests that haematin (probably in the form of a haemoprotein) is a component of the nitratase enzyme system of the organism and that linked reactions between hydrogen donors and nitrate can provide energy necessary for growth.

\section{Reduction of nitrate by suspensions of the variant staphylococcus and the assay of haematin}

Requirements for nitrate reduction. The organism grew well on the complex medium A which contained acetate but not haematin; the yield of organisms after incubation for $18 \mathrm{hr}$. was about $0.5 \mathrm{mg}$. dry wt./ml. culture. Organisms 
harvested from this medium formed only traces of nitrite from nitrate when incubated with buffered glucose, but active reduction occurred when haematin was added (Table 3 ). Protoporphyrin (up to $10^{-5} \mathrm{M}$ ) did not replace haematin even in the presence of added iron $\left(10^{-5} \mathrm{M}\right)$. The organisms reduced nitrate to some extent in the presence of phosphate and haematin only; presumably endogenous substances in the cells served as hydrogen donors. Addition of glucose greatly increased the formation of nitrite (Table 3).

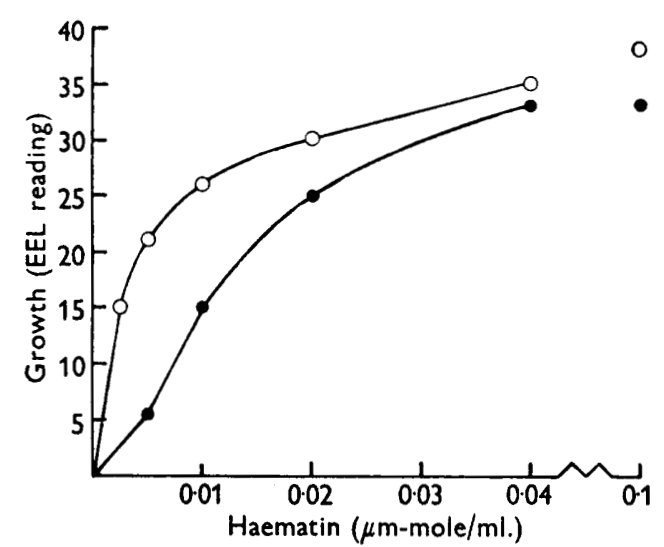

Fig. 1



Fig. 2

Fig. 1. Effect of haematin on growth of the staphylococcus variant. The cultures were incubated for $22 \mathrm{hr}$. in medium $B$ in air (-) or in medium $B$ with $0.01 \mathrm{M}-\mathrm{NaNO}_{3}$ under an atmosphere of $5 \% \mathrm{CO}_{2}(\mathrm{v} / \mathrm{v})$ in $\mathrm{H}_{2}(\mathrm{O}-\mathrm{O})$.

Fig. 2. Rate of nitrite formation from nitrate by suspensions of the staphylococcus variant. The organisms (1.3 mg./ml. dry wt.) were incubated in $0.1 \mathrm{~m}$-phosphate buffer, $\mathrm{pH} 6 \cdot 9$, with $0.02 \mathrm{M}$-glucose, $0.008 \mathrm{M}-\mathrm{NaNO}_{3}$ and $6 \times 10^{-8} \mathrm{M}$-haematin.

Table 3. Requirements for reduction of nitrate to nitrite by suspensions of the staphylococcus variant

Organisms (3.2 mg. dry wt.) were incubated for $5 \mathrm{hr}$. in $0 \cdot 1 \mathrm{~m}-$ phosphate buffer (pH 6.9) with the additions shown; the final volume was $2.5 \mathrm{ml}$.

Additions

$\begin{array}{cccc}\mathrm{NaNO}_{3} & \begin{array}{c}\text { Glucose } \\ (0.002 \mathrm{M})\end{array} & \begin{array}{c}\text { Haematin } \\ \left(10^{-6} \mathrm{M}\right)\end{array} & \begin{array}{c}\text { Nitrite formed } \\ (\mu \mathrm{m}-\mathrm{mole} / \mathrm{ml} .)\end{array} \\ + & + & + & 650 \\ - & + & + & 0 \\ + & - & + & 125 \\ + & + & - & 1\end{array}$

Course of the reaction. The rate of nitrite formation increased gradually during the first $2 \mathrm{hr}$. of incubation, but became linear thereafter (Fig. 2). The initial lag may have been due to the formation of an adaptive enzyme; the formation of nitratase by suspensions of coliform organisms is an adaptive process (Pollock, 1946). Inclusion of nitrate in the growth medium did not alter the behaviour of the harvested suspensions. 
The amount of nitrite formed was only a small fraction $(c .9 \%)$ of the theoretical value for complete reduction of the added nitrate. This low yield was not due to further reduction of nitrite (for instance to ammonia) since added nitrite was recovered quantitatively after incubation with organisms in the presence of buffered glucose and haematin.

The assay of haematin. The amount of nitrite formed from nitrate was proportional to the amount of haematin over a range of concentration from 0.04 to $0.25 \mu \mathrm{m}$.-mole/ml. (Fig. 3). In assays of haematin, organisms were suspended in buffered glucose with nitrate and incubated for 4-5 hr. with

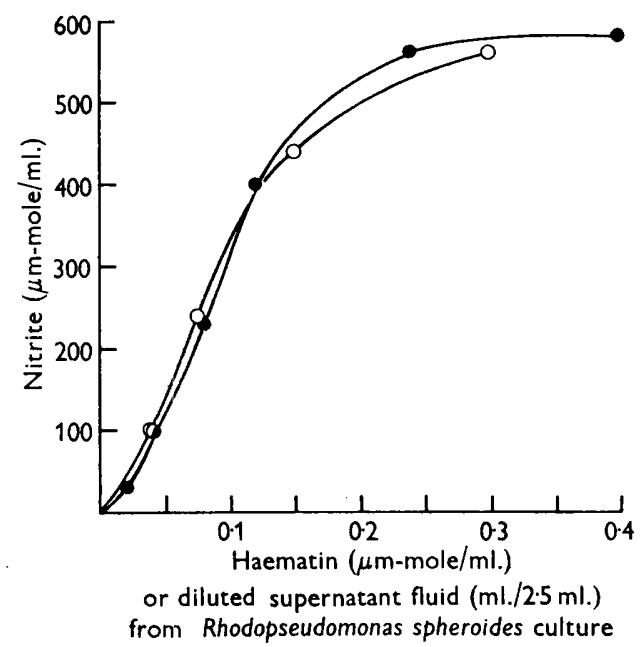

Fig. 3. The effect of concentration of haematin (-) or of supernatant fluid from Rhodopseudomonas spheroides $(\mathrm{O}-\mathrm{O})$ on the formation of nitrite by suspensions of the staphylococcus variant. The organisms $(1.2 \mathrm{mg} . / \mathrm{ml}$. dry wt.) were incubated for

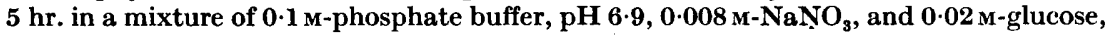
with addition of haematin or diluted sample.

addition of the sample under assay. A standard series was included in each assay with concentrations of haematin ranging from 0.03 to $0 \cdot 4 \mu \mathrm{m}-\mathrm{mole} / \mathrm{ml}$. and a curve was constructed relating the concentration of nitrite formed to the amount of haematin. The concentration of haematin in the unknowns was calculated from the standard curve. Haematin could be estimated by this method with an accuracy of $\pm 20 \%$; the assay was about 100 times more sensitive than the spectrophotometric method for the estimation of pyridine haemochromogen (Drakbin, 1942), which is suitable only for concentrations of $5 \mu \mathrm{m}-\mathrm{mole} / \mathrm{ml}$. or more.

The formation of iron protoporphyrin by suspensions of Rhodopseudomonas spheroides

Suspensions of Rhodopseudomonas spheroides form porphyrins (mainly coproporphyrin type III) when incubated anaerobically in the light with glycine and $\alpha$-oxoglutarate (Lascelles, 1956). $\delta$-Aminolaevulic acid (ALA) is also con- 
verted to porphyrins under similar conditions and behaves as if it were an intermediate between glycine $+\alpha$-oxoglutarate and the porphyrins. Coproporphyrin type III is formed predominantly from ALA when the organisms are incubated in phosphate buffer with $\mathrm{Mg}^{++}$only; the further addition of an oxidizable substrate, such as fumarate, together with iron salts, results in the formation of both protoporphyrin and coproporphyrin.

Table 4. The requirements of Rhodopseudomonas spheroides for synthesis of iron protoporphyrin and porphyrin from $\delta$-aminolaevulic acid

;anisms ( $1.2 \mathrm{mg}$. dry wt./ $\mathrm{ml}$. in both experiments) were incubated in $0.08 \mathrm{M}$-phosphate ( $\mathrm{pH} 6.9)$ containing ${ }^{1-4} \mathrm{M}-\mathrm{MgSO}_{4}$ and additions shown ; total volume, $2 \cdot 5 \mathrm{ml}$. Incubation was in the light under $\mathrm{H}_{2}$ for $22 \mathrm{hr}$. .. 1) and $15 \mathrm{hr}$. (Expt. 2).

\begin{tabular}{|c|c|c|c|c|c|c|}
\hline \multirow[b]{2}{*}{$\begin{array}{l}\text { aevulic } \\
\text { acid } \\
\text { (M) }\end{array}$} & Additions & $\longrightarrow$ & & & \multicolumn{2}{|c|}{$\begin{array}{l}\text { Percentage of ether-soluble } \\
\text { porphyrin present as } \dagger\end{array}$} \\
\hline & $\begin{array}{c}\text { Iron } \\
\text { citrate } \\
\left(2 \times 10^{-5} \mathrm{M}\right)\end{array}$ & $\begin{array}{c}\text { Carboxylic } \\
\text { acid } \\
\left(4 \times 10^{-3} M\right)\end{array}$ & $\begin{array}{c}\text { Iron } \\
\text { protoporphyrin } \\
(\mu \mathrm{m}-\mathrm{mole} / \mathrm{ml} .)\end{array}$ & $\begin{array}{c}\text { Porphyrin* } \\
(\mu \mathrm{m}-\mathrm{mole} / \mathrm{ml} .)\end{array}$ & $\begin{array}{c}\text { Copro- } \\
\text { porphyrin }\end{array}$ & $\begin{array}{c}\text { Proto- } \\
\text { porphyrin }\end{array}$ \\
\hline \multirow{6}{*}{$2 \times 10^{-3}$} & - & - & $<0.5$ & 101 & 100 & 0 \\
\hline & + & - & $<0.5$ & 99 & 100 & $\mathbf{0}$ \\
\hline & - & Fumarate & $0 \cdot 6$ & 72 & 92 & 8 \\
\hline & + & Fumarate & 30 & 65 & 80 & 20 \\
\hline & + & Lactate & 32 & 83 & 78 & 22 \\
\hline & + & Acetate & 34 & 64 & 81 & 19 \\
\hline 0 & + & Fumarate & $<0.5$ & $\mathbf{0}$ & . & . \\
\hline $5 \times 10^{-4}$ & + & Fumarate & $0 \cdot 7$ & 17 & . & . \\
\hline $1 \times 10^{-3}$ & + & Fumarate & 6 & 34 & 78 & 22 \\
\hline $2 \times 10^{-3}$ & + & Fumarate & 18 & 77 & 76 & 24 \\
\hline $4 \times 10^{-3}$ & + & Fumarate & 23 & 103 & 84 & 16 \\
\hline $2 \times 10^{-3}$ & - & Fumarate & $<0.5$ & 94 & 95 & $\mathbf{5}$ \\
\hline $2 \times 10^{-3}$ & + & - & $<0.5$ & 99 & 98 & 2 \\
\hline
\end{tabular}

Further experiments showed that the suspensions also formed a substance which promoted growth of the staphylococcus in the absence of haematin; it was produced only under conditions which favoured the formation of protoporphyrin. The active substance was identified as iron protoporphyrin by several methods (see later) and has been assayed by the nitratase method. It was present in the supernatant fluid after removal of the organisms by centrifugation; no attempt was made to determine the iron protoporphyrin which may have been present either in free or bound form within the organisms.

Conditions for the formation of iron protoporphyrin. Iron protoporphyrin as well as protoporphyrin and coproporphyrin were formed by Rhodopseudomonas spheroides when incubated anaerobically in the light with ALA, fumarate (or other oxidizable substrates) and iron (Table 4). These compounds were all essential for the synthesis of maximum amounts of iron protoporphyrin and of protoporphyrin; formation of coproporphyrin, however, occurred in the absence of fumarate and iron. The concentration of iron required for maximum 
production of iron protoporphyrin was about five times greater than that needed for the formation of protoporphyrin (Table 5).

Table 5. The effect of concentration of iron on production of iron protoporphyrin and protoporphyrin by Rhodopseudomonas spheroides

Organisms (1.2 mg. dry wt. $/ \mathrm{ml}$.) were suspended in $0.08 \mathrm{M}$-phosphate, pH 6.9, $8 \times 10^{-4} \mathrm{M}$ $\mathrm{MgSO}_{4}, 4 \times 10^{-3} \mathrm{M}$-fumarate and $2 \times 10^{-3} \mathrm{M}$-ALA with addition of iron (as the citrate). Incubation was for $22 \mathrm{hr}$. in the light under $\mathbf{H}_{2}$.

\begin{tabular}{|c|c|c|c|c|}
\hline \multirow{2}{*}{$\begin{array}{l}\text { Added iron } \\
(\mathrm{M})\end{array}$} & \multirow{2}{*}{$\begin{array}{c}\text { Iron proto- } \\
\text { porphyrin } \\
(\mu \mathrm{m}-\mathrm{mole} / \mathrm{ml} .)\end{array}$} & \multirow{2}{*}{$\begin{array}{c}\text { Porphyrin* } \\
(\mu \mathrm{m}-\mathrm{mole} / \mathrm{ml} .)\end{array}$} & \multicolumn{2}{|c|}{$\begin{array}{c}\text { Percentage ether-soluble porphyrin } \\
\text { present as } \dagger\end{array}$} \\
\hline & & & Coproporphyrin & Protoporphyrin \\
\hline o & $<0.5$ & 98 & 97 & $\mathbf{3}$ \\
\hline $4 \times 10^{-6}$ & 2 & 92 & 89 & 11 \\
\hline $1 \times 10^{-5}$ & 11 & 85 & 76 & 24 \\
\hline $2 \times 10^{-5}$ & 24 & 85 & 85 & 15 \\
\hline $4 \times 10^{-5}$ & 30 & 81 & 85 & 15 \\
\hline $1 \times 10^{-4}$ & 32 & 85 & 89 & 11 \\
\hline
\end{tabular}

Iron protoporphyrin was not formed when the organisms were incubated in the light with protoporphyrin up to $50 \mu \mathrm{m}-\mathrm{mole} / \mathrm{ml}$. in the presence of fumarate and iron. Therefore, the iron protoporphyrin found in systems containing ALA presumably did not arise by chemical or enzymic reaction between iron salts and the protoporphyrin formed concurrently from ALA.

Neither porphyrins nor iron protoporphyrin were formed when the organisms were incubated anaerobically in the dark. Little or no iron protoporphyrin was synthesized by aerobically-grown organisms incubated aerobically in the dark with ALA, fumarate and iron; under these conditions protoporphyrin as well as coproporphyrin is formed though the yield of por-


the light (Lascelles, 1956).

Effect of cobalt ions. The synthesis of iron protoporphyrin from ALA was inhibited by $\mathrm{Co}^{++}$at concentrations similar to that of the iron present (Table 6). Synthesis was not affected by $\mathrm{Zn}^{++}, \mathrm{Pb}^{++}, \mathrm{Ni}^{++}$nor by ammonium molybdate (each tested at $10^{-5} \mathrm{M}$ ).

Cobalt also inhibited the formation of protoporphyrin (Table 6), suggesting that its locus of action may be at a stage before the insertion of iron into the porphyrin nucleus. Cobalt has been found to inhibit incorporation of radioactive glycine into haem by preparations of rabbit bone marrow (Laforet \& Thomas, 1956).

Identification of iron protoporphyrin. The response to haematin of the staphylococcus in the nitratase assay was similar to that obtained with graded amounts of supernatant fluid obtained from experiments with $R$ hodopseudomonas spheroides (Fig. 3). Also, a strictly additive effect was obtained on addition of supernatant fluid together with suboptimal concentrations of haematin. 
Further evidence that the material formed by Rhodopseudomonas spheroides was iron protoporphyrin was obtained by examination of concentrates by paper chromatography and by spectroscopy. Pooled supernatant fluids from typical experiments were adjusted to $\mathrm{pH} 4$ with acetic acid and extracted with ether; the ethereal extracts contained both porphyrins and iron protoporphyrin. The free porphyrins were removed by extraction with $1 \cdot 4, \mathrm{~N}-\mathrm{HCl}$, leaving the iron protoporphyrin in the ether phase. After washing with water,

Table 6. Effect of cobalt ions on formation of iron protoporphyrin and porphyrins by Rhodopseudomonas spheroides

Organisms (1.4 mg. dry wt./ml.) were suspended as in Table 5 ; iron was added as the citrate. Incubation was for $21 \mathrm{hr}$. in the light under $\mathbf{H}_{\mathbf{2}}$.

\begin{tabular}{|c|c|c|c|c|c|}
\hline \multicolumn{2}{|c|}{ Additions } & \multirow{2}{*}{$\begin{array}{c}\text { Iron proto- } \\
\text { porphyrin } \\
(\mu \mathrm{m}-\mathrm{mole} / \mathrm{ml} .)\end{array}$} & \multirow[b]{2}{*}{$\begin{array}{c}\text { Porphyrin* } \\
(\mu \mathrm{m}-\mathrm{mole} / \mathrm{ml} .)\end{array}$} & \multicolumn{2}{|c|}{$\begin{array}{l}\text { Percentage ether-soluble } \\
\text { porphyrin present as } \dagger\end{array}$} \\
\hline $\begin{array}{l}\text { Iron } \\
(\mathrm{M})\end{array}$ & $\begin{array}{l}\mathrm{CoCl}_{2} \\
(\mathrm{M})\end{array}$ & & & $\begin{array}{l}\text { Copro- } \\
\text { porphyrin }\end{array}$ & $\begin{array}{c}\text { Proto- } \\
\text { porphyrin }\end{array}$ \\
\hline 0 & $\mathbf{0}$ & 0.2 & 104 & 98 & 2 \\
\hline $1 \times 10^{-5}$ & 0 & 8 & 96 & 82 & 18 \\
\hline $4 \times 10^{-5}$ & o & 32 & 93 & 84 & 16 \\
\hline $1 \times 10^{-5}$ & $4 \times 10^{-6}$ & 7 & 93 & 95 & 5 \\
\hline $4 \times 10^{-5}$ & $4 \times 10^{-6}$ & 10 & 86 & 94 & 6 \\
\hline $1 \times 10^{-5}$ & $1 \times 10^{-5}$ & 2 & 89 & 100 & $\mathbf{0}$ \\
\hline $4 \times 10^{-5}$ & $1 \times 10^{-5}$ & 5 & 93 & 100 & $\mathbf{0}$ \\
\hline $1 \times 10^{-5}$ & $4 \times 10^{-5}$ & $<0.05$ & 98 & 100 & $\mathbf{0}$ \\
\hline $4 \times 10^{-5}$ & $4 \times 10^{-5}$ & $<0.05$ & 96 & 100 & o \\
\hline
\end{tabular}

the ether was distilled off and a brown residue with high activity for the variant staphylococcus remained. This material gave a single spot (visible under ultraviolet irradiation) with an $\boldsymbol{R}_{\boldsymbol{r}}$ value identical with that of haematin, when examined by the method of Chu \& Chu (1955) using reverse-phase paper chromatography. Solutions of the concentrate in $0.01 \mathrm{~N}-\mathrm{NaOH}$ were converted to the pyridine haemochromogen derivative and examined with a Hartridge reversion spectroscope (R. and J. Beck Ltd., London, W. 1). The absorption bands at 557.5 and $528.7 \mathrm{~m} \mu$. coincided with those found with pure haematin extracted and treated under the same conditions.

\section{DISCUSSION}

The ability of acetate and pyruvate to replace haematin for growth of the variant staphylococcus suggests that they are products, though not necessarily direct ones, of a reaction in which haematin is concerned. Organisms grown with haematin contain cytochromes (Jensen \& Thofern, 1953a, 1954) and these presumably participate in the ultimate stages of electron transfer to oxygen. When the cytochrome system is available to the organism, pyruvate and acetate may be formed from precursors derived by oxidation of glucose or of amino acids. In the absence of haematin pyruvate and acetate, if formed, do 
not accumulate in amounts sufficient to promote growth of the organism. Acetate is formed by the anaerobic dissimilation of pyruvate by other strains of Staphylococcus aureus (Krebs, 1937). It is likely that the variant can convert pyruvate to acetate irrespective of the presence of haematin and that the metabolic block caused by the absence of haematin results in a complete or partial inability to form pyruvate. An examination of the metabolism of glucose and other carbon compounds by the organism grown with and without haematin is clearly necessary before the growth-promoting action of pyruvate and acetate can be fully understood.

Both pyruvate and acetate are known to be essential metabolites for other micro-organisms. Pyruvate is needed for growth of a saprophytic treponeme (S-69) on a chemically defined medium (Steinman, Oyama \& Schulze, 1954). Acetate is essential for growth of some lactobacilli in the absence of lipoic (thioctic) acid; this cofactor is needed for the oxidative decarboxylation of pyruvate to acetate (Gunsalus, 1954). Lipoic acid had no effect on the requirement of the staphylococcus variant for pyruvate or ace ate.

The stimulatory effect of nucleic acid derivatives on growth with pyruvate or acetate in the absence of haematin suggests that precursors of these compounds are formed most efficiently when the cytochrome system is available. This is further suggested by the observation that uracil is essential for the anaerobic growth of Staphylococcus aureus but is not riecessary for aerobic growth (Richardson, 1936).

Nitrate is utilized by the staphylococcus variant as a terminal hydrogen acceptor in growing cultures just as effectively as oxygen, provided that haematin is present. The organism is therefore capable of true dissimilatory nitrate reduction as defined by Kluyver (1953) and Verhoeven \& Goos (1954). The experiments with growing cultures and with suspensions of the staphylococcus variant indicate that haematin, probably as a haemoprotein, participates in the reduction of nitrate by this organism. The nitrate reductase may therefore be similar to that in Haemophilus influenzae; in this organism nitrite production from nitrate occurs in cultures grown with haematin (or with protoporphyrin) but is not found in cultures grown with other iron porphyrins which support growth (Granick \& Gilder, 1946; Smith, Hale \& O'Callaghan, 1953). There is also evidence that cytochromes participate in the reduction of nitrate by cell-free extracts of Escherichia coli (Sato \& Egami, 1949; Sato \& Niwa, 1952). A similar function of cytochromes in the reduction of sulphate by Desulphovibrio desulphuricans is suggested by the work of Postgate (1955, 1956). Haematin is not, however, a component of nitrate reductase prepared in purified form from $E$. coli and Neurospora; in these preparations reduction of nitrate to nitrite is catalysed $\mathrm{by}$ a molybdo-flavoprotein (Nicholas \& Nason, 1954, 1955). It is possible, therefore, that there may be several types of nitrate reductase enzymes in micro-organisms.

The synthesis of iron protoporphyrin by Rhodopseudomonas spheroides from $\delta$-aminolaevulic acid occurs simultaneously with the formation of protoporphyrin. The present experiments provide no indication of the stage at which iron is inserted into the porphyrin nucleus. If it is incorporated after 


\section{Utilization and synthesis of iron protoporphyrin}

the formation of free protoporphyrin it might be expected that the organisms would form iron protoporphyrin when incubated with protoporphyrin and iron, but this was not found. Protoporphyrir may not penetrate into the cells; on the other hand, iron may be attached to a precursor of protoporphyrin before completion of the final product. Iron is also necessary for the synthesis of free protoporphyrin from ALA but is required at a lower concentration ( $c$. fivefold) than is needed for demonstrable formation of iron protoporphyrin. The experiments do not show whether the function of iron in the conversion of ALA to protoporphyrin is connected with the synthesis of iron protoporphyrin.

I am extremely grateful to Professor D. D. Woods, F.R.S., for his constant encouragement and advice. I am also indebted to Dr J. H. Marshall for details of the method used to estimate nitrite.

\section{REFERENCES}

Chu, T. C. \& ChU, E. J.-H. (1955). Paper chromatography of iron complexes of porphyrins. J. biol. Chem. 212, 1.

Drabkin, D. L. (1942). Spectrophotometric studies. X. Structural interpretation of the spectra of cyanide, pyridine and carbon monoxide derivatives of cytochrome $c$ and haemoglobin. J. biol. Chem. 146, 605.

ElsDen, S. R. (1954). The utilization of organic compounds by photosynthetic bacteria. In Autotrophic Microorganisms. Symp. Soc. gen. Microbiol., 4, 202. Cambridge University Press.

Gilder, H. \& Granick, S. (1947). Studies on the Haemophilus group of organisms. Quantitative aspects of growth on various porphin compounds. J. gen. Physiol. 31, 103.

Granick, S. \& Gilder, H. (1946). The porphyrin requirements of Haemophilus influenzae and some functions of the vinyl and propionic acid side chains of haem. J. gen. Physiol. 30, 1.

Grinstein, M. \& Wintrobe, M. M. (1948). Spectrophotometric micromethod for the quantitative determination of the free erythrocyte protoporphyrin. $J$. biol. Chem. 172, 459 .

Gursalus, I. C. (1954). Group transfer and acyl-generating functions of lipoic acid derivatives. In The Mechanism of Enzyme Action, p. 545. Ed. McElroy, W. D. \& Glass, B. Baltimore: The Johns Hopkins Press.

Jensen, J. \& Thofern, E. (1953a). Chlorohämin (Ferriporphyrinchlorid) als Bakterienwuchsstoff. I. Z. Naturf. $8 b, 599$.

Jensen, J. \& Thofern, E. (1953b). Chlorohämin (Ferriporphyrinchlorid) als Bakterienwuchsstoff. II. Zur Synthese der Hämatinfermente. Z. Naturf. 8b, 604 .

Jensen, J. \& Thofenn, E. (1953c). Chlorohämin (Ferriporphyrinchlorid) als Bakterienwuchsstoff. III. Competitive Hemmung der Hämatinfermentsynthese. Z. Naturf. $8 b, 697$.

Jensen, J. \& Thofers, E. (195-1). Chlorohämin (Ferriporphyrinchlorid) als Bakterienwuchsstoff. IV. Zum Cytochromsystem von $M$. pyog. var aureus. Z. Naturf. $9 b, 596$.

Kanten, M. D. (1955). Bacterial haem proteins. Part 2 of symposium on electron transport in the metabolism of microorganisms. Bact. Rev. 19, 250.

Klcyver, A. J. (1953). Some aspects of nit rate reduction. Symposium on Microbial Metabolism, p. 71. VIth Congr. int, Microbiol. Rome.

Krebs, H. A. (1937). Dismutation of pyruvic acid in gonococcus and staphylococcus. Biochem. J. 31, 661. 
Laforet, M. T. \& Thomas, E. D. (1956). The effect of cobalt on haem synthesis by bone marrow in vitro. J. biol. Chem. 218, 595.

LASCElles, J. (1955). The formation of porphyrins by photosynthetic bacteria. In The Biosynthesis of Porphyrins and Porphyrin Metabolism, Ciba Foundation Conf. p. 265. Ed. Wolstenholme, G. E. W. London: J. and A. Churchill Ltd.

LAscelles, J. (1956). The synthesis of porphyrins and bacteriochlorophyll by cell suspensions of Rhodopseudomonas spheroides. Biochem. J. 62, 78.

Lascelles, J. \& Woods, D. D. (1952). The synthesis of 'folic acid' by Bacterium coli and Staphylococcus aureus and its inhibition by sulphonamides. Brit. J. exp. Path. 33, 288.

Lemberg, R. \& Legge, J. W. (1949). Haematin Compounds and Bile Pigments. London: Interscience Publishers Ltd.

Lwoff, M. (1951). The nutrition of parasitic flagellates (Trypanosomidae, Trichomonadinae). Chapter in Protozoa, 1, p. 129. Ed. A. Lwoff. New York: Academic Press Inc.

Nicholas, D. J. D. \& Nason, A. (1954). Mechanism of action of nitrate reductase from Neurospora. J. biol. Chem. $211,183$.

Nicholas, D. J. D. \& Nason, A. (1955). Diphosphopyridine nucleotide-nitrate reductase from Escherichia coli. J. Bact. 69, 580.

Niel, C. B. van (1944). The culture, general physiology, morphology and classification of the non-sulphur purple and brown bacteria. Bact. Rev. 8,1 .

Pollock, M. R. (1946). Adaptation of 'nitratase' in washed suspensions of bacteria. Brit. J. exp. Path. 27, 419.

Postgate, J. R. (1955). Cytochrome $c_{3}$, a bifunctional haematohaematin. Biochim. biophys. Acta, 18, 427.

Postgate, J. R. (1956). Cytochrome $c_{3}$ and desulphoviridin; pigments of the anaerobe Desulphovibrio desulphuricans. J. gen. Microbiol. 14, 545.

Richardon, G. M. (1936). The nutrition of Staphylococcus aureus. Necessity for uracil in anaerobic growth. Biochem. $J .30,2184$.

Rider, B. F. \& Mellon, M. G. (1946). Colorimetric determination of nitrites. Industr. Engng Chem. (Anal.), 18, 96.

Sato, R. \& Egami, F. (1949). Studies on nitrate reductase. III. Bull. chem. Soc. Japan, 22, 137.

Sato, R. \& Niwa, M. (1952). Studies on nitrate reductase. VII. Reinvestigation on the identity of the enzyme with cytochrome b. Bull. chem. Soc. Japan, 25, 202.

Smith, W., Hale, J. H. \& O'Callaghan, C. H. (1953). Haem utilization and nitrate reduction by Haemophilus influenzae. J. Path. Bact. 65, 229.

Steinman, H. G., Oyama, V. I \& Schulze, H. O. (1954). Carbon dioxide, cocarboxylase, citrovorum factor and coenzyme $A$ as essential growth factors for a saprophytic treponeme (S-69). J. biol. Chem. 211, 327.

Verhoeven, W. \& Goos, J. J. C. (1954). Studies on true dissimilatory nitrate reduction. 1. Fate of the hydrogen donator in bacterial nitrate reduction. Leeuwenhoek ned. Tijdschr. $20,93$.

Vernon, L. P. \& Kamen, M. D. (1954). Haematin compounds in photosynthetic bacteria. J. biol. Chem. 211, 643. 